\title{
Sleep apnea and snoring
}

宫

Supplemental data at www.neurology.org
A 42-year-old man was evaluated for snoring and sleep apnea. Overnight polysomnography revealed 28 events per hour on the apnea-hypopnea index. To determine the site of obstruction and determine treatment, dynamic MRI with concurrent EEG monitoring in natural sleep was performed. We recorded 2 mechanisms of total occlusion: at the oropharyngeal level and due to movement of the uvula during snoring (videos 1 and 2). ${ }^{1}$ Two different mechanisms suggested against surgical therapy; he was treated with a continuous positive airway pressure mask at $7 \mathrm{~cm} \mathrm{H} \mathrm{H}_{2} \mathrm{O}$, with a good outcome.

Pavel Kavcic, MD, Ales Koren, MD, PhD, Blaz Koritnik, MD, PhD, Leja Dolenc Groselj, MD, PhD

From University Medical Center Ljubljana, Slovenia.

Author contributions: Dr. Kavcic: study concept or design, analysis or interpretation of data, drafting or revising the manuscript. Dr. Koren: study concept or design, analysis or interpretation of data. Dr. Koritnik: study concept or design. Dr. Dolenc Groselj: study concept or design, drafting or revising the manuscript, study supervision.

Study funding: No targeted funding reported.

Disclosure: The authors report no disclosures relevant to the manuscript. Go to Neurology.org for full disclosures.

Correspondence to Dr. Kavcic: pavel.kavcic@gmail.com

1. Kuipers AF, Bartels LW. Sleep apnea. N Engl J Med 2012;367:e33. 


\title{
Neurology
}

\author{
Sleep apnea and snoring \\ Pavel Kavcic, Ales Koren, Blaz Koritnik, et al. \\ Neurology 2013;81;691 \\ DOI 10.1212/WNL.0b013e3182a08d6a
}

This information is current as of August 12, 2013

Updated Information \&
Services
Supplementary Material
References
Subspecialty Collections

Subspecialty Collections

Permissions \& Licensing

Reprints including high resolution figures, can be found at: http://n.neurology.org/content/81/7/691.full

Supplementary material can be found at: http://n.neurology.org/content/suppl/2013/08/11/81.7.691.DC1

This article cites 1 articles, 0 of which you can access for free at: http://n.neurology.org/content/81/7/691.full\#ref-list-1

This article, along with others on similar topics, appears in the following collection(s):

MRI

http://n.neurology.org/cgi/collection/mri

Sleep apnea

http://n.neurology.org/cgi/collection/sleep_apnea

Information about reproducing this article in parts (figures,tables) or in its entirety can be found online at:

http://www.neurology.org/about/about_the_journal\#permissions

Information about ordering reprints can be found online:

http://n.neurology.org/subscribers/advertise

Neurology ${ }^{\circledR}$ is the official journal of the American Academy of Neurology. Published continuously since 1951, it is now a weekly with 48 issues per year. Copyright () 2013 American Academy of Neurology. All rights reserved. Print ISSN: 0028-3878. Online ISSN: 1526-632X.

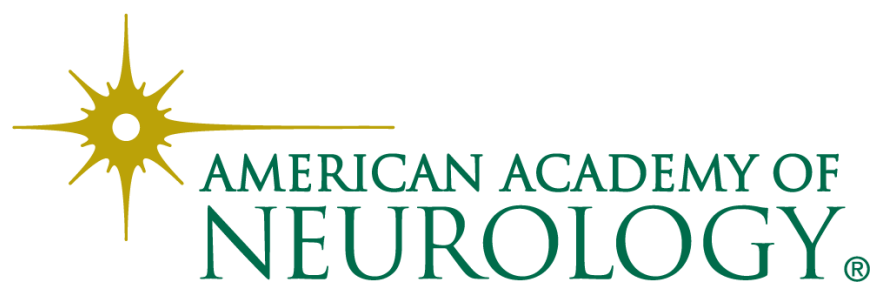

